\title{
Albert Montgomery Kligman
}

\author{
MD, PhD, Dr. h.c. mult., Professor of Dermatology
}

\section{Gerd Plewig}

Department of Dermatology and Allergology, Ludwig Maximilian University, Munich, Germany

\section{The Man behind the Name}

Polls are the barometers of academic names. Ask any dermatologist, young or old, anywhere on the globe: 'Who is Albert Kligman?' He has the highest recognition factor of all. Why? Let us take a closer look at this man.

\section{His Roots}

Both of his parents emigrated in their childhood from Eastern Europe to America during that time period between 1875 and 1910, when some 40 million people immigrated to the New World. His parents settled in Philadelphia, were married by arrangement and had 2 children, a son (Albert) and a daughter (Mimi). Albert Montgomery Kligman is thus a first-generation American. $\mathrm{He}$ was born on March 17, 1916, on what is celebrated in the USA and, of course, in Ireland as St. Patrick's Day, into a world of turmoil, trouble, depression and poverty. His parents struggled for the bare essentials and for their children. Academia was a word not known in the family's language.

I will refer to our honoree and my dear friend as Albert for the rest of this talk.
Prof. Albert Kligman

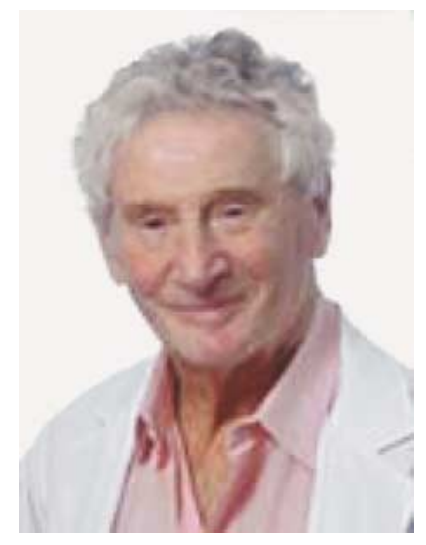

Prof. Gerd Plewig

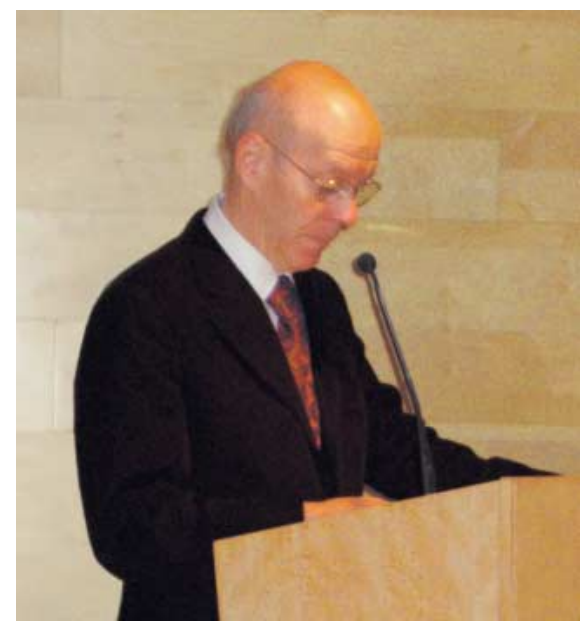

Prof. Dr. med. Dr. h.c. Gerd Plewig, FRCP

Klinik und Poliklinik für Dermatologie und Allergologie

Ludwig-Maximilians-Universität München, Frauenlobstrasse 9-11

DE-80337 München (Germany), Tel. +49 8951606000

Fax+498951606002, E-Mail Gerd.Plewig@med.uni-muenchen.de
Fax + 41613061234

E-Mail karger@karger.ch

www. karger.com
(C) 2004 S. Karger AG, Basel

Accessible online at:

www. karger.com/drm 


\section{Early Fate}

Albert went his own way at an early age. He decided to study rather than entering the depressed job market. $\mathrm{He}$ was admitted to Pennsylvania State College and managed to finance his studies through the generosity of the local Jewish community, as the rabbi of his synagogue collected enough funds to provide Albert with 100 dollars a month. During his 4 years (1935-1939) as a Nittany Lion, Albert distinguished himself academically and was a member of the gymnastics team. The next step was graduate school at the University of Pennsylvania from 1939 to 1942, also supported by scholarship funds. In just 3 years, he obtained a PhD in botany.

How Albert got into medical school is a fascinating story which he can tell you over a bottle of Jack Daniels. In any event, he received another scholarship at the University of Pennsylvania, entered medical school and graduated in 1947 as a rare species, especially for that period, an MD, $\mathrm{PhD}$ : the rest is easy. After his internship, he entered the renowned Pennsylvania dermatology program and has remained there and in Philadelphia until these very days.

Albert has never forgotten that the 4 elements for success, according to the surgeon Christian Barnard - ability (which he has in plenty), opportunity (which was offered to him), imagination (plentiful in his genes) and luck (which he has had all through his life) -, helped him to rise from his humble family background into the forefront of academic medicine.

\section{The Art of Giving}

Now you know why Albert has been so generous to so many of us. He and his wife Lorraine, a $\mathrm{PhD}$, are supporters and givers not on a reciprocal scale but in immeasurable magnitudes. Scholarships for students, donations to institutions and many other endowments - this is how the Kligmans show their appreciation for their good fortune. They are on a constant goodwill tour. The contributions of Albert, supported by his wife Lori, dwarf those of many of his contemporaries and previous colleagues.

\section{The Many Facets of the Dermatologist, Researcher and Scholar}

Don't think Albert has always been as you see him now. Under no circumstances was he always an easy colleague and teacher. His clearness of thinking, his striving to analyze complex issues in a logical way, his tendency to dissect painfully what others for the sake of diplomacy handle softly - all produced sharp sword-like remarks. I don't know how often I have witnessed Albert in action at conferences, when he stood up and said things which others would scarcely dare to think ... but things which needed to be said, bringing clarity of thought to a situation but often at the cost of laughter, protest or even a bit of friendly humiliation. Albert never really set out to hurt anyone; he just said what he thought. It took me a long while to get used to these verbal attacks, which unloaded themselves like unexpected migraines.

One must also talk about the brilliancy of his tongue. How often did he and still does surprise the audience with his unsurpassed witty but fitting verbal showers. He keeps asking and literally attacking others to tell us why they did this research or concluded such things, thus pointing out the senselessness of the work they did, by measuring or assessing without asking a meaningful question. Often he spiced his attacks with special remarks like 'It looks like French cooking', 'This is like Smorgasbord buffet' or 'Shopping in a supermarket'.

Albert stepped, as a researcher, into new territories like Lewis and Clark in the USA discovering the West or Sven Hedin into Arabian deserts. His discoveries are legend. Let me name a few as pars pro toto:

- The PAS stain for the demonstration of fungi

- Poison ivy dermatitis

- Acne, sebaceous glands and the benefit or uselessness of sebum

- Patch testing to identify contact allergens

- Stratum corneum and barrier of the skin

- Retinoids to treat acne and photodamaged skin

- Sweating and producing anhidrosis

- Photobiology and the evil effects of UV radiation

- He also crafted books. A cornerstone is A Manual of Cutaneous Medicine by Pillsbury, Shelley and Kligman. The other one is on his beloved topic, Acne and Rosacea, which came in 3 editions and 2 languages, where both of us poured our hearts into text and pictures

I have to stop here, otherwise I would use up too much time to remind you of all his fundamental thoughts and writings.

By the way, his writing is a piece of art. His text is always a beautiful creation, his style is unique, clear and fascinating. He has command of the language like not many others. This explains his pivotal role as a speaker. Whenever and wherever Albert appears at a conference, he finds a full house. His lectures are distinctive - a mas- 
terful blend of brilliant ideas and sparkling language. His ability as a lecturer is legendary.

\section{The Teacher and His Students}

In his role as a teacher, Albert has trained many young researchers from all over the world. They flocked around him to be as close to the Master as possible. Most of them were assigned to pursue an idea he already had firmly impressed in his mind. He pushed, urged, was interested, listened to interim reports, but never applied inappropriate pressure. He wanted the ideas to germinate naturally. Most of his fellows were academically nourished by his wisdom and inspiration. Not all of his students survived in academia. But why should they? There is a natural selection. Albert can be proud and evidently is to see his scientific genes spread out over the globe. Some of the students became colleagues, even good friends, to the great delight of Albert.

\section{Honors and Tokens of Appreciation}

Let us look at just some of the great honors Albert has received throughout his long career. The Doctor honoris causa of the University of Utrecht, The Netherlands, in 1968 as well as the one of the Heinrich Heine University in Düsseldorf, Germany, in 1990 belong to this category. He was President of the Society for Investigative Dermatology and holds the Stephen Rothman Award and Medal.

Albert is witty enough to see all this in the right perspective: 'You only have to live long enough to receive honors.' He is not only right, but he truly deserves these honors.

Another highly esteemed token is the 'Festschrift' in the Archives of Dermatological Research, dedicated to him on the occasion of his 65 th birthday.

\section{Fund Raising and Paying Back}

Not every hero of our own specialty has the unselfish capacity to return what he was fortunate enough to receive earlier in life. One of the remarkable aspects of Albert's personality is his unbroken will and mental power to generously pay back what was bestowed upon him. For instance, he raised a substantial amount of money and gave his own share for an Albert Montgomery Klig- man Endowment Chair. This has been used in the past to employ 2 renowned professors of dermatology in his alma mater, the University of Pennsylvania in Philadelphia. This will perpetuate indefinitely. Many other fund-raising campaigns were successfully managed by Albert. He is just too modest to speak about this.

\section{Living with Family and Friends}

The Kligmans enjoy life with high intensity. Between their condominium in a high rise in Central Philadelphia within sight of the University of Pennsylvania and a beautiful beach home on an island off the New Jersey shore, Lorraine and Albert arrange their life in a liberal, openhearted and gracious way. Both of them love the arts as well as nature with flowers and trees, superbly arranged in and around their house. Philharmonic concerts and opera performances are important parts in their life. They are surrounded by beautiful items, which they love and discuss with friends.

Albert truly has had good luck throughout his life. This is not to say that he was always spared from attacks, accusations and envy. He must have, what Benjamin Franklin, the great father of the city of Philadelphia, invented: a personal lightning rod. Otherwise I could not understand how he survived some of these assaults.

His great luck, highly appreciated by himself and truly witnessed by his intimate friends, is Lori, his beloved wife. She neutralizes what may be induced by his caustics. She superbly rules house, kitchen and table. Albert's lust to eat and enjoy food and share it with friends at the table is always richly provided by Lori Kligman. I have rarely encountered a man speaking of, sniffling at and smelling the dishes with such outbursts of joy, animation and gustatory noises, including olfactory sneezes. Marvelous expeditions into restaurants are memorabilia. I would like to name but two: Gerd Käfer in Munich and Mr. Rettich, the blimp, in Düsseldorf. Albert, you know what I mean!

\section{Friendship}

Albert has his view of friendship. He was or is friendly with many but has also lost friendships which he has had for years or even decades. Now that he is finally old enough to contemplate and analyze what makes a true lasting friendship, he has become philosophical. His inner circle of true friends receives his warm-hearted love over and over again. 


\section{A Rich Harvest}

Albert often states that he has received more in his life than he ever dared to dream of. He was able to rise through his own discipline and the intensive lust to live, richly supported in early life by others. He climbed higher than many others, achieved a respected academic position not only at home in Philadelphia, but also in the USA and throughout the world. He battled with some physical ailments and overcame all of them. His body, mind and heart are strong. He is a man of wisdom and power.

Early up every morning he still dives into the lagoon water at the age of 87 years. He is thankful, happy and grateful. He has a brilliant mind and is abreast with the academic world. He is a mensch, master, scholar and giver.

\section{References}

Pillsbury DM, Shelley WB, Kligman AM: Dermatology. Philadelphia, Saunders, 1956.

Plewig G, Kligman AM: Acne. Berlin, Springer, 1975.

Plewig G, Kligman AM: Akne. Berlin, Springer, 1978.

Plewig G, Maibach HI: Festschrift in honour of Albert Montgomery Kligman, MD, PhD, Dr. h.c. mult. Arch Dermatol Res 1982;272:191464.
Plewig G, Kligman AM: Acne and Rosacea, ed 2, completely revised. Berlin, Springer, 1993.

Plewig G, Kligman AM: Akne und Rosazea, 2. neubearbeitete Auflage. Berlin, Springer, 1994.

Plewig G, Kligman AM: Acne and Rosacea, ed 3 , completely revised and enlarged. Berlin, Springer, 2000. 